\title{
Osteopontin as a Novel Biomarker for the Prognosis and Clinical Pathology of Prostate Cancer: A Systematic Review and Meta-Analysis
}

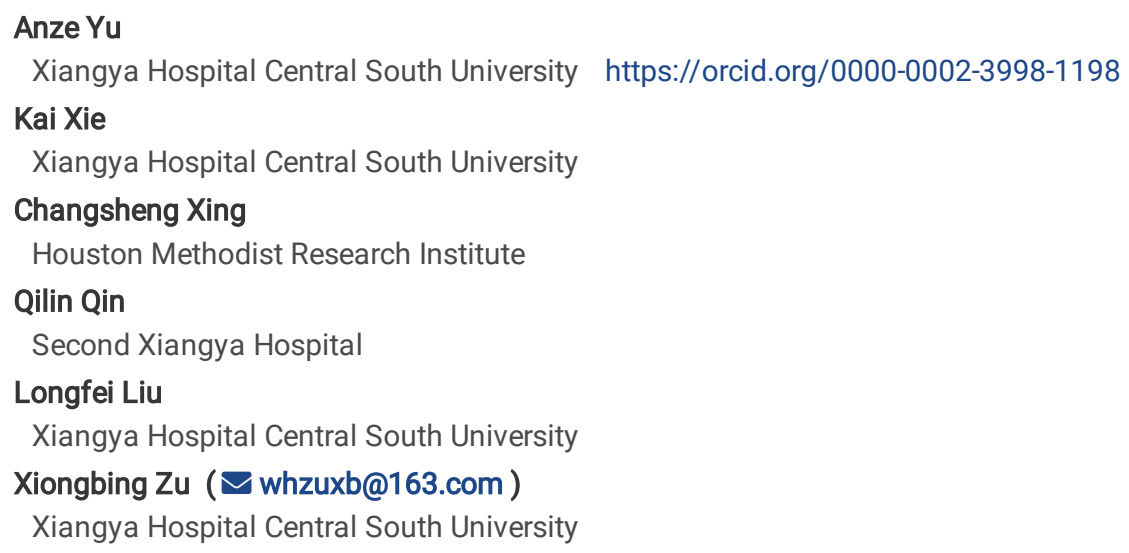

Research

Keywords: Osteopontin, survival, prognosis, prostate cancer, biomarker

Posted Date: September 18th, 2020

DOI: https://doi.org/10.21203/rs.3.rs-72826/v1

License: @ (i) This work is licensed under a Creative Commons Attribution 4.0 International License. Read Full License 


\section{Abstract}

Background: Evaluation of the feasibility for osteopontin (OPN) to serve as a biomarker in the prognosis and clinical pathological features of prostate cancer patients.

Methods: The original publications related to osteopontin and prostate cancer were comprehensively searched in the online databases, including PubMed, Embase, Cochrane Library, Web of Science, Medline, Wanfang database and China National Knowledge Infrastructure up to August 2019. Results were analyzed by software Revman 5.3 and Stata 12.0.

Results: A total of 21 studies were included in the analysis and the result showed that the positive OPN expression group had a lower overall survival than the negative expression group (univariate: $\mathrm{HR}=2.32,95 \% \mathrm{Cl}[1.74,3.10]$, multivariate: $\mathrm{HR}=2.41,95 \% \mathrm{Cl}[1.63,3.57]$ ) and a lower biochemical relapse-free survival than the negative group (univariate: $\mathrm{HR}=1.42,95 \% \mathrm{Cl}[0.92,2.17]$, multivariate: $\mathrm{HR}=1.61,95 \% \mathrm{Cl}[1.39$, 1.87]). In addition, there was a higher expression level of OPN in prostate cancer tissues than in normal prostate tissues $(\mathrm{OR}=46.55,95 \% \mathrm{Cl}[12.85,168.59]$, $\mathrm{p}<0.00001)$ and benign prostatic hyperplasia tissues (OR=11.07, 95\% CI [3.43, 35.75], $\mathrm{p}<0.0001)$. Moreover, OPN positive expression was also related to high Gleason score $(\mathrm{OR}=2.64,95 \% \mathrm{Cl}[1.49,4.70], \mathrm{p}=0.0009)$, high TNM stage $(\mathrm{OR}=3.15,95 \% \mathrm{Cl}[1.60,6.20$, $\mathrm{p}=0.0009)$, high Whitmore-Jewett stage $(\mathrm{OR}=2.53,95 \% \mathrm{Cl}[1.06,6.03], \mathrm{p}=0.04)$, high lymph node $(\mathrm{OR}=3.69,95 \% \mathrm{Cl}[1.88,7.23], \mathrm{p}=0.0001)$, and distant metastasis $(\mathrm{OR}=8.10,95 \% \mathrm{Cl}[2.94$, 22.35], $p=0.01)$. There was no difference observed in the differentiation of prostate cancer $(\mathrm{OR}=1.79,95 \% \mathrm{Cl}[0.39,8.33], \mathrm{p}=0.46)$.

Conclusion: Osteopontin could be recognized as a promising novel diagnostic and prognostic biomarker for prostate cancer patients.

\section{Introduction}

Prostate cancer (PCA) is the second most common malignancy in males, with an increasing risk in aged population [1, 2]. Current major clinical diagnostic methods for prostate cancer include prostate specific antigen (PSA) level test, trans-anal prostate ultrasound, prostate magnetic resonance, and needle biopsy [3-7]. Although the elevation of PSA is usually recognized as an indicator of prostate cancer in clinical diagnosis, sometimes its production can also be induced by benign prostatic hyperplasia or inflammation. Furthermore, the expression of PSA does not increase in some highly differentiated prostate cancer cases [8]. Therefore, it will be critical to discover novel secretory biomarkers, which are directly associated with the clinical pathological features of prostate cancer, to enable its convenient diagnosis and prognosis.

Osteopontin (OPN), as one of the major bone matrix proteins, is widely distributed across organs and tissues, and plays an important role in modulating inflammation and tumor responses [9]. As a cytokine homologous to matrix proteins, OPN is critical in regulating the adhesion between cells and extracellular matrix, mineralization and reconstruction of bones, cell migration and movement,[10]. OPN can also promote the cell proliferation and differentiation, long-term survival and invasion in a variety of tumors such as non-small cell lung carcinoma, prostate neoplasm, hepatic neoplasm, breast neoplasm, malignant melanoma, and colorectal neoplasm [11-17]. Consistently, an increased expression level of OPN has been observed in the peripheral blood of the patients with multiple types of tumors, compared with healthy donors, and it exhibits a positive correlation with the invasiveness and malignancy of these cancers [10].

Although OPN has the potential to serve as a novel biomarker for the diagnosis of prostate cancer and an indicator of the level of malignancy, unfortunately, it still lacks large-scale clinical trials and a systematic analysis. Therefore, we conduct this systemic review and meta-analysis to evaluate the possibility of OPN as a biomarker for the diagnosis, malignancy, and prognosis of prostate cancer patients.

\section{Materials And Methods}

\section{The criteria of inclusion:}

All the studies were case-controlled or randomized-controlled trials.

None of the patients or healthy donors ever received any radiotherapy, chemotherapy, or hormone therapy before sampling.

All the original clinical pathological data can be obtained directly.

The detection of osteopontin expression were based on the pathological examination to determine the presence of prostate cancer tissue, rather than speculating the presence of prostate cancer by PSA, MRI, CT or Doppler ultrasound.

The best data quality was selected in duplicated studies.

\section{The criteria of exclusion:}

Animal or cell studies.

Case report, review, meta-analysis. 
Insufficient data from original studies.

\section{Searching strategies}

The literatures were comprehensively searched in the online databases, including PubMed, Embase, Cochrane Library, Web of Science, Medline, Wanfang database and China National Knowledge Infrastructure up to August 2019. The Clinicaltrial.gov was also searched. All the studies or clinical trials were restricted to Homo sapiens, but not by time, race, data source, language, age or publication status. The following MeSH searching terms were used: (osteopontin) or (Sialoprotein 1) or (Secreted Phosphoprotein 1) or (Bone Sialoprotein 1) or (Sialoprotein 1, Bone) or (Bone Sialoprotein I) or (Sialoprotein I, Bone) or (Uropontin) AND (Prostate Neoplasms) or (Neoplasms, Prostate) or (Neoplasm, Prostate) or (Prostate Neoplasm) or (Neoplasms, Prostatic) or (Prostate Cancer) or (Prostate Cancers). Our search strategy has been adjusted according to different databases.

\section{Quality evaluation of the included studies}

We used the Newcastle-Ottawa quality assessment scale of case control studies (NOS) as the method to assess the quality of included studies. All the studies have a score range from 6 to 9 , which proved that they are suitable for the inclusion.

\section{Data extraction and statistical analysis}

All the included articles were full-test reviewed and the data were extracted by two reviewers independently. The methodological differences of classification were solved after discussion by the whole authors. The extracted data were dichotomous and analyzed by software Revman 5.3 and Stata 12.0. The results of the analyses were shown by the OR (odds ratio) and 95\% confidence interval $(95 \% \mathrm{Cl})$.

Sensitivity analysis was performed to rule out the impact of a specific study when the heterogeneity of the results was large $\left(P<0.1\right.$ or $\left.I^{2}>50 \%\right)$. Finally, all the included articles were tested for publication bias through Begg's test and risk of bias summary.

\section{Results}

\section{Characteristics of the included literatures}

A total of 663 studies were searched and identified (Figure 1), including 119 from Pubmed, 301 from Embase, 20 from CNKI, 15 from Wanfang database, 4 from Cochrane Library, 120 from Google Scholar, 80 from Web of Science and 4 from Clinicaltrial.gov. Next, 252 studies were excluded for duplication. The rest of studies were carefully examined on Title, Abstract, and Key words, and 357 were excluded because they do not match the subject of this meta-analysis. The full text of remaining 54 studies were carefully reviewed and 33 of them were excluded as animal or cell studies ( $n=18)$, case report, review, meta-analysis $(n=7)$, and insufficient data from original studies ( $n=8)$. As a result, 21 studies were included for the quality evaluation through the Newcastle-Ottawa scale (NOS). The details of the included studies and the NOS score of each study were shown in Tables 1 and 2.

\section{Osteopontin expression and overall survival}

In the overall survival analysis, three univariate studies and three multivariate studies were analyzed separately. The univariate studies had no heterogeneity $\left(p=0.981, \mathrm{I}^{2}=0 \%\right)$, so a fixed-effects model was used and showed that the OPN positive group had a lower overall survival than the negative group $(H R=2.32,95 \% \mathrm{Cl}[1.74,3.10], p<0.05)$. Besides, the multivariate studies also had no heterogeneity $\left(p=0.682, I^{2}=0 \%\right)$, so the fixedeffects model was used and presented the same result $(\mathrm{HR}=2.41,95 \% \mathrm{Cl}[1.63,3.57], \mathrm{p}<0.05)$ (Figure $2 \mathrm{~A})$. In conclusion, the positive expression of OPN is not conducive to the overall survival in prostate cancer patients.

\section{Osteopontin expression and biochemical relapse-free survival}

Biochemical relapse of prostate cancer stands for the re-elevation of PSA level in prostate cancer patients underwent clinical therapy. A total of three studies, including 4 univariate analyses and 4 multivariate analyses, were selected for evaluating the association of OPN expression and biochemical relapse-free survival. The univariate studies had a high heterogeneity $\left(p=0.010, l^{2}=78.5 \%\right)$, so the random-effects model was used and showed that the OPN positive group had a lower biochemical relapse-free survival than the negative group $(\mathrm{HR}=1.42,95 \% \mathrm{Cl}[0.92,2.17], \mathrm{p}<0.05)$. Sensitivity analysis showed that the result was stable. In addition, the multivariate studies had no heterogeneity $\left(p=0.469, I^{2}=0 \%\right)$, so the fixedeffects model was used and the same result $(\mathrm{HR}=1.61,95 \% \mathrm{Cl}[1.39,1.87], \mathrm{p}<0.05)$ was observed (Figure 2B).

\section{Osteopontin expression and other survival studies}

Except the overall survival and biochemical relapse-free survival analyses, some studies also mentioned the OPN expression with distant metastasis-free survival, progression-free survival, and disease-specific survival. Although these studies all showed that OPN positive group had a lower survival rate (Figure $2 \mathrm{C}$ ), respectively, the results were not conclusive in our meta-analysis due to the lack of relevant studies. 
A total of 5 studies reported the expression of OPN between prostate cancer tissues and normal prostate tissues, including 271 prostate cancer tissue samples and 132 normal prostate tissue samples. The heterogeneity of the obtained results is low ( $p=0.25, l^{2}=26 \%$ ), so the fixed-effects model is adopted and showed that the expression of OPN in prostate cancer tissues was significantly higher than that in normal prostate cancer tissues $(\mathrm{OR}=46.55,95 \% \mathrm{Cl}[12.85,168.59]$, $\mathrm{p}<0.00001)$ (Figure $3 \mathrm{~A})$. Then, we performed the sensitivity analysis on the obtained results and excluded individual studies one by one. The heterogeneity did not change significantly, which proves that our conclusion was stable and reliable (Figure $5 \mathrm{~A}$ ). In summary, there was higher expression level of OPN in prostate cancer tissues than in normal prostate tissues.

\section{Osteopontin expression between prostate cancer tissues and benign prostatic hyperplasia}

A total of 9 studies reported the comparison of OPN expression in patients with prostate cancer (PCA) and benign prostatic hyperplasia (BPH), including 469 PCA tissue samples and $263 \mathrm{BPH}$ tissue samples. The results obtained from the analysis had a high heterogeneity ( $<<0.00001$, $\mathrm{I}^{2}=81 \%$ ), so the random-effects model was adopted. To further determine the stability and reliability of the results, we performed a sensitivity analysis of the included literatures to determine whether individual studies would have an impact on the results. And we found that the heterogeneity decreased after excluding the study of Tozawa[18], with the conclusion that there was higher expression level of OPN in PCA tissues than in $\mathrm{BPH}$ tissues $(\mathrm{OR}=11.07,95 \% \mathrm{Cl}[3.43,35.75]$, $\mathrm{p}<0.0001)$. The result was stable and acceptable (Figure 5B). In summary, the expression of OPN in PCA tissues was higher than in BPH tissues (Figure 3B).

\section{Osteopontin expression with the Gleason score of prostate cancer}

Gleason score is a widely used histological scoring system in prostate cancer, which is associated with the prognosis and biological behavior. A total of 9 studies reported the relationship between OPN expression and the Gleason score of PCA tissues, including 148 high Gleason score samples (>8) and 282 low Gleason score samples ( $\leq 7)$. The result had no heterogeneity $\left(p=0.88, I^{2}=0 \%\right)$, and the fixed-effects model was adopted (Figure 4A). The studies of Forootan and Tilli found that all the prostate cancer tissues were positively stained with OPN, and they compared the Gleason score to the staining intensity of OPN. Although all prostate cancer tissues were positive for OPN staining from their studies, the prostate cancer tissues with high Gleason score had a stronger staining when compared with the low Gleason score tissues. In conclusion, the expression level of OPN was positively correlated with the Gleason score of prostate cancer $(\mathrm{OR}=2.64,95 \% \mathrm{Cl}[1.49,4.70], \mathrm{p}=0.0009)$.

\section{Osteopontin expression with the clinical TNM stage of prostate cancer}

A total of 4 studies included the relationship between osteopontin and the clinical TNM stage of prostate cancer, among which $93 \mathrm{~T}$ III-IV stage patients and $155 \mathrm{~T} \mathrm{I-II}$ stage patients were reported. The results had no heterogeneity $\left(\mathrm{p}=0.49, \mathrm{I}^{2}=0 \%\right)$, and the fixed-effects model was adopted (Figure 4B). Overall, the expression level of OPN in T III-IV stage was higher than that in $\mathrm{T}$ I-II stage of prostate cancer patients $(\mathrm{OR}=3.15,95 \% \mathrm{Cl}$ $[1.60,6.20], p=0.0009)$.

\section{Osteopontin expression with the Whitmore-Jewett stage of prostate cancer}

Whitmore-Jewett stage is the most common staging strategery in clinical practice. This staging method divides prostate cancer into 4 stages (A, B, C, D) according to the degrees of infiltration. A total of 4 studies reported the relationship between osteopontin and the Whitmore-Jewett stage of prostate cancer, including 89 stage $C+D$ patients and 130 stage $A+B$ patients. The results had a low heterogeneity $\left(p=0.19, l^{2}=38 \%\right)$, and the fixedeffects model was used (Figure 4C). When we conducted the sensitivity analysis and excluded the studies in turn, we found that the heterogeneity did not change significantly, so the analysis results were stable. Over all, the expression level of OPN in Whitmore-Jewett stage C+D patients was higher than in stage $A+B$ patients $(O R=2.53,95 \% \mathrm{Cl}[1.06,6.03], p=0.04)$.

\section{Osteopontin expression with the differentiation of prostate cancer}

A total of 6 studies reported the relationship between osteopontin and the differentiation of prostate cancer, including 233 low differentiation samples and 124 high differentiation samples. The results had a significant heterogeneity $\left(p<0.00001, l^{2}=87 \%\right)$, so the random-effects model was adopted and showed that the expression of OPN had no difference between high and low differentiation of prostate cancer tissues $(\mathrm{OR}=1.79,95 \% \mathrm{Cl}$ $[0.39,8.33], p=0.46)$ (Figure 4D). Then we conducted a sensitivity analysis, and after removing each study one by one, the heterogeneity remained constant, which proved that our results were reliable. In conclusion, there was no significant correlation between the expression level of OPN with the differentiation of prostate cancer.

\section{Osteopontin expression with the lymph node metastasis of prostate cancer}

Lymph node metastasis of tumors is often associated with poor prognosis, so the early diagnosis and judgment of lymph node metastasis is essential. A total of 4 studies included the relationship between the OPN and lymph node metastasis of prostate cancer, including 290 prostate cancer tissues. The result had a low heterogeneity $\left(p=0.16, I^{2}=42 \%\right)$, so the fixed-effects model was adopted, and showed that the expression of 
OPN was positively correlated with lymph node metastasis of prostate cancer (OR=3.69, 95\% $\mathrm{Cl}[1.88,7.23], \mathrm{p}=0.0001)$ (Figure 4E). Sensitivity analysis showed the result was stable.

\section{Osteopontin with the distant metastasis of prostate cancer}

Distant metastasis including bone or organ metastasis are the most common forms of metastasis in patients with prostate cancer and usually bring a poor prognosis. Three articles including 198 patients have reported the correlation between prostate cancer distant metastasis and OPN. The results had no heterogeneity $\left(p=0.44, l^{2}=0 \%\right)$, so the fixed-effects model was adopted, and showed that the expression of OPN was positively correlated with distant metastasis of prostate cancer $(\mathrm{OR}=8.10,95 \% \mathrm{Cl}[2.94,22.35], \mathrm{p}=0.01)$ (Figure $4 \mathrm{~F})$. Sensitivity analysis showed that the result was stable.

\section{Publication bias}

After analyzing all the results, we examined whether there was publication bias in the included literatures by using Begg's test, and the conclusions showed that there was no significant publication bias in each analysis (Figure 6), so the results were reliable and stable. Besides, we also conducted the risk of bias summary diagram to show the source of potential bias (Figure 7).

\section{Discussion}

Prostate cancer is an epithelial malignancy with the second highest incidence rate in aged men, and the patients are usually treated with castration therapy or surgery $[9,19-24]$. However, there still lack of effective treatments for advanced metastatic prostate cancer and castration-resistant prostate cancer. OPN is a secreted phosphorylated glycoprotein which is very important in the cell proliferation and differentiation of various malignant tumors[25]. It is also involved in bone metabolism, induces angiogenesis, inhibits the killing function of immune cells in the tumor microenvironment, thereby promoting tumor invasion and metastasis[11, 26, 27]. Increasing studies report that OPN is associated with the proliferation and metastasis of a variety of tumors, including breast cancer, stomach cancer, prostate cancer, liver cancer, and esophageal cancer[8, $10,25,28-30]$.

OPN binds to its receptor integrin and regulates the migration, adhesion, and mobilization of tumor cells, which is related to the invasion and proliferation ability of multiple cancers[31]. Firstly, we investigated the expression of OPN with the survival analyses (overall survival, biochemical relapse-free survival, disease specific survival, distant metastasis-free survival and progression-free survival) in prostate cancer patients and all the results showed that the high expression of OPN could decrease the survival time. Meanwhile, we also analyzed the expression of OPN in different types of prostate tissues, and found that the positive expression rate of OPN in prostate cancer tissues is higher when compared with BPH tissues and normal tissues. However, some studies also showed a different conclusion. Forootan [32] showed that OPN had a high positive expression rate in BPH and normal tissues. Tillis's research showed that there was a similar level of OPN expression between prostate cancer tissues and BPH tissues. Therefore, we need more researches and evidences to further solve this problem.

In addition, our meta-analysis compared the expression of OPN in relation to the clinical pathological parameters of prostate cancer such as Gleason score, the clinical TNM stage, the Whitmore-Jewett stage, the differentiation, the lymph node and distant metastasis. Overall, the expression of OPN was positively correlated with the malignant degree and metastatic ability of prostate cancer. However, comparisons showed that there was no obvious correlation between the expression of OPN and the degree of prostate cancer differentiation. We reason that it is due to the subjectivity of different researchers for them to define the degree of differentiation, because some researchers categorized the poorly and moderately differentiated prostate cancers together, while others categorized the moderately and highly differentiated prostate cancers together. Therefore, the correlation between the positive expression rate of OPN and the differentiation of prostate cancer was still uncertain, and more researches are needed to achieve a conclusion.

In addition to the detection of OPN expression in prostate tissue by IHC, some scholars have also detected OPN expression in blood and urine by ELISA[11, 33, 34]. The results showed that the expression of OPN in prostate cancer patients was significantly higher than that in healthy person. In addition, OPN protein expression was detected by western blot, and its mRNA expression was detected by qPCR[28, 35]

OPN expression has been indicated to correlate with cancer prognosis and survival. Lindahl's [36] study has shown that OPN can serve as an inflammatory mediator to the pathogenesis of breast cancer. Feng's [37] study shows that the upregulation of OPN is not conducive to the survival in human lung cancers. However, our study is the first meta-analysis to discuss the relationship between survival and OPN expression, and we also evaluate the expression of OPN in different prostate tissues and different clinical parameters. Meanwhile, some restrictions and limitations still exist in our study. Firstly, our meta-analysis selected the data from published literatures rather than all raw data, so our results of the analyses may deviate from the true values if the cited articles have bias. Secondly, different studies often choose various criteria for judging the expression level of OPN, which may lead to some different conclusions.

\section{Conclusion}


The results of our meta-analysis indicate that OPN positive expression is not conducive to overall survival and biochemical relapse-free survival in prostate cancer patients. OPN has a higher positive rate in prostate cancer than in BPH tissues and normal tissue. In addition, the positive rate of OPN expression was positively correlated with Gleason score, TNM stage, Whitmore-Jewett stage, lymph node metastasis, and bone metastasis.

\section{Abbreviations}

OPN: osteopontin; PCA: Prostate cancer; PSA: prostate specific antigen; NOS :Newcastle-Ottawa quality assessment scale of case control studies; OR: odds ratio; Cl: confidence interval; IHC: Immunohistochemistry; ELISA: Enzyme-linked immunosorbent assay; mCRPC: metastatic castrateresistant prostate cancer; LPC: localized prostate cancer; mADPC: metastatic androgen-dependent prostate cancer; PA: prostate adenocarcinoma; HRPC: hormone-refractory prostate carcinoma; Cohort l: radiotherapy cohort, Cohort II: radical prostatectomy cohort; OS: overall survival; BRFS: biochemical relapse-free survival; DMFS: distant metastasis-free survival; PFS: progression-free survival; DSS: disease-specific survival; U: univariate analysis, $\mathrm{M}$; multivariate analysis

\section{Declarations}

\section{Ethics approval and consent to participate}

Not applicable.

\section{Consent for publication}

Not applicable.

\section{Availability of data and materials}

Not applicable.

\section{Conflicts of Interests}

The authors declare that the research was conducted in the absence of any commercial or financial relationships that could be construed as a potential conflict of interest.

\section{Funding}

This work was supported by the National key R\&D Program of China (2016YFC0902603), the National Natural Science Foundation of China [81572523, 81700665]

\section{Author Contributions}

$\mathrm{AY}$ and $\mathrm{KX}$ designed the study and conducted the experiment and wrote down the manuscript, $\mathrm{CX}$ help analyze the result and gave writing suggestions, LL help review the manuscript, XZ guided the study. All the authors approved the final version of the manuscript.

\section{Acknowledgements}

Not applicable.

\section{References}

1. Tannock IF. Improving Treatment for Advanced Prostate Cancer. The New England journal of medicine 381(2), 176-177 (2019).

2. Chen W, Yao G, Zhou K. miR-103a-2-5p/miR-30c-1-3p inhibits the progression of prostate cancer resistance to androgen ablation therapy via targeting androgen receptor variant 7. Journal of cellular biochemistry 120(8), 14055-14064 (2019).

3. Desai NB, Courtney K, Subramaniam RM, Cadeddu JA. Salvage Radiotherapy for Nodal Oligorecurrent Prostate Cancer: A Step Towards Predictive Criteria for Metastasis-Directed Therapy in Prostate Cancer? European urology doi:10.1016/j.eururo.2019.07.050 (2019).

4. Donzelli A, Castelluzzo G, Giudicatti G. Re: Jonas Hugosson, Monique J. Roobol, Marianne Mansson, et al. A 16-yr Follow-up of the European Randomized Study of Screening for Prostate Cancer. Eur Urol 2019;76:43-51: Mortality in the Age Group >/=70yr and the Case of Italy. European urology doi:10.1016/j.eururo.2019.07.045 (2019).

5. Drost FH, Nieboer D, Morgan TM, Carroll PR, Roobol MJ. Predicting Biopsy Outcomes During Active Surveillance for Prostate Cancer: External Validation of the Canary Prostate Active Surveillance Study Risk Calculators in Five Large Active Surveillance Cohorts. European urology doi:10.1016/j.eururo.2019.07.041 (2019). 
6. Glaser AW. Resilience of men and the gap hypothesis of quality of life: Health utility outcome measurement in prostate cancer. European urology doi:10.1016/j.eururo.2019.07.046 (2019).

7. Huang C, Deng H, Wang Y et al. Circular RNA circABCC4 as the ceRNA of miR-1182 facilitates prostate cancer progression by promoting FOXP4 expression. Journal of cellular and molecular medicine 23(9), 6112-6119 (2019).

8. Bhattacharya IS, Hoskin PJ, Sharabiani MTA, Alonzi R. The use of angiogenic and hypoxia biomarkers to predict the benefit from dose escalation using external beam radiotherapy plus a high dose-rate brachytherapy boost compared to external beam radiotherapy alone in localized prostate cancer. Brachytherapy 15 S74-S75 (2016).

9. Adamik J, Roodman GD, Galson DL. Epigenetic-Based Mechanisms of Osteoblast Suppression in Multiple Myeloma Bone Disease. JBMR Plus 3(3), (2019).

10. Badowska-Kozakiewicz AM, Budzik MP. The multidirectional role of osteopontin in cancer. Nowotwory 68(4), 176-183 (2018).

11. Castellano G, Malaponte G, Mazzarino MC et al. Activation of the osteopontin/matrix metalloproteinase-9 pathway correlates with prostate cancer progression. Clinical cancer research : an official journal of the American Association for Cancer Research 14(22), 7470-7480 (2008).

12. Castilla C, Flores ML, Conde JM et al. Downregulation of protein tyrosine phosphatase PTPL1 alters cell cycle and upregulates invasion-related genes in prostate cancer cells. Clinical \& experimental metastasis 29(4), 349-358 (2012).

13. Chaplet M, Waltregny D, Detry C, Fisher LW, Castronovo V, Bellahcene A. Expression of dentin sialophosphoprotein in human prostate cancer and its correlation with tumor aggressiveness. International journal of cancer 118(4), 850-856 (2006).

14. Dayyani F, Zurita AJ, Nogueras-Gonzalez GM et al. The combination of serum insulin, osteopontin, and hepatocyte growth factor predicts time to castration-resistant progression in androgen dependent metastatic prostate cancer- an exploratory study. BMC cancer 16721 (2016).

15. Ge C, Zhao G, Li Y et al. Role of Runx2 phosphorylation in prostate cancer and association with metastatic disease. Oncogene 35(3), 366-376 (2016).

16. Huang J, Duran A, Reina-Campos M et al. Adipocyte p62/SQSTM1 Suppresses Tumorigenesis through Opposite Regulations of Metabolism in Adipose Tissue and Tumor. Cancer cell 33(4), 770-784.e776 (2018).

17. Isebaert S, Haustermans K, Van Den Bergh L et al. Identification and characterization of nodal metastases in prostate cancer patients at high risk for lymph node involvement. Acta oncologica (Stockholm, Sweden) 52(7), 1336-1344 (2013).

18. Tozawa K, Yamada Y, Kawai N, Okamura T, Ueda K, Kohri K. Osteopontin expression in prostate cancer and benign prostatic hyperplasia. Urologia internationalis 62(3), 155-158 (1999).

19. Aalinkeel R, Abou-Jaoude E, Parikh N et al. Galectin-3 in prostate cancer proliferation and metastasis. European journal of immunology 46227 (2016).

20. Akech J, Wixted JJ, Bedard K et al. Runx2 association with progression of prostate cancer in patients: mechanisms mediating bone osteolysis and osteoblastic metastatic lesions. Oncogene 29(6), 811-821 (2010).

21. Al Nakouzi N, Bawa O, Le Pape A et al. The IGR-CaP1 xenograft model recapitulates mixed osteolytic/blastic bone lesions observed in metastatic prostate cancer. Neoplasia (New York, N. Y.) 14(5), 376-387 (2012).

22. Lv Z, Jiang H, Hu X et al. Efficacy and safety of periprostatic nerve block combined with perineal subcutaneous anaesthesia and intrarectal lidocaine gel in transrectal ultrasound guided transperineal prostate biopsy: A Prospective Randomised Controlled Trial. Prostate cancer and prostatic diseases doi:10.1038/s41391-019-0155-0 (2019).

23. Zhang G, Li Y, Li C, Li N, Li Z, Zhou Q. Assessment on clinical value of prostate health index in the diagnosis of prostate cancer. Cancer medicine 8(11), 5089-5096 (2019).

24. Wang R, Zhang M, Ou Z et al. Long noncoding RNA DNM30S promotes prostate stromal cells transformation via the miR-29a/29b/COL3A1 and miR-361/TGFbeta1 axes. Aging 11 (2019).

25. Angelucci A, Festuccia C, Gravina GL et al. Osteopontin enhances the cell proliferation induced by the epidermal growth factor in human prostate cancer cells. The Prostate 59(2), 157-166 (2004).

26. Caruso DJ, Carmack AJ, Lokeshwar VB, Duncan RC, Soloway MS, Lokeshwar BL. Osteopontin and interleukin-8 expression is independently associated with prostate cancer recurrence. Clinical cancer research : an official journal of the American Association for Cancer Research 14(13), 4111-4118 (2008).

27. Chang AC, Chen PC, Lin YF et al. Osteoblast-secreted WISP-1 promotes adherence of prostate cancer cells to bone via the VCAM-1/integrin alpha4beta1 system. Cancer letters 426 47-56 (2018).

28. Anunobi CC, Koli K, Saxena G, Banjo AA, Ogbureke KU. Expression of the SIBLINGs and their MMP partners in human benign and malignant prostate neoplasms. Oncotarget 7(30), 48038-48049 (2016).

29. Arbeit JM, Brown JM, Chao KSC et al. Hypoxia: Importance in tumor biology, noninvasive measurement by imaging, and value of its measurement in the management of cancer therapy. International Journal of Radiation Biology 82(10), 699-757 (2006).

30. Brown LF, Papadopoulos-Sergiou A, Berse B et al. Osteopontin expression and distribution in human carcinomas. The American journal of pathology 145(3), 610-623 (1994). 
31. Fradet A, Sorel H, Depalle B et al. A New Murine Model of Osteoblastic/Osteolytic Lesions from Human Androgen-Resistant Prostate Cancer. PloS one 8(9), (2013).

32. Forootan SS, Foster CS, Aachi VR et al. Prognostic significance of osteopontin expression in human prostate cancer. International journal of cancer 118(9), 2255-2261 (2006).

33. Anborgh PH, Wilson SM, Tuck AB et al. New dual monoclonal ELISA for measuring plasma osteopontin as a biomarker associated with survival in prostate cancer: clinical validation and comparison of multiple ELISAs. Clinical chemistry 55(5), 895-903 (2009).

34. Dayyani F, Nogueras-Gonzalez GM, Slack R et al. Serum insulin to predict time to castration-resistant progression and overall survival in metastatic androgen-dependent prostate cancer (mADPCa). Journal of Clinical Oncology 31(15), (2013).

35. Briese J, Schulte HM, Bamberger CM, Loning T, Bamberger AM. Expression pattern of osteopontin in endometrial carcinoma: correlation with expression of the adhesion molecule CEACAM1. International journal of gynecological pathology : official journal of the International Society of Gynecological Pathologists 25(2), 161-169 (2006).

36. Lindahl G, Rzepecka A, Dabrosin C. Increased Extracellular Osteopontin Levels in Normal Human Breast Tissue at High Risk of Developing Cancer and Its Association With Inflammatory Biomarkers in situ. Front Oncol 9746 (2019).

37. Feng YH, Su YC, Lin SF et al. Oct4 upregulates osteopontin via Egr1 and is associated with poor outcome in human lung cancer. BMC cancer 19(1), 791 (2019)

38. Tilli TM, Silva EA, Matos LC et al. Osteopontin is a tumor autoantigen in prostate cancer patients. Oncology Letters 2(1), 109-114 (2011).

39. Wang CQ. The function and meaning of Protein P27ロSurvivin $\square$ OPN and Clusterin in prostate cancer tissues. CNKI. (2016).

40. Wu Yudong, Liu Bingqian, Zhang Xuepei, Wei Jinxing, Wu Changli. Detection of osteopontin and matrix metalloproteinase-2 in prostate cancer tissues. Journal of Zhengzhou University (Medical Sciences) (04), 654-656 (2005).

41. Tilli TM, Thuler LC, Matos AR et al. Expression analysis of osteopontin mRNA splice variants in prostate cancer and benign prostatic hyperplasia. Experimental and molecular pathology 92(1), 13-19 (2012).

42. Zheng Aiping, Shi Bentao, Zhao Yang et al. Expression and clinical significance of osteopontin gene in prostate cancer. Journal of Modern Urology 19(01), 48-51 (2014).

43. Flajollet S, Tian TV, Flourens A et al. Abnormal expression of the ERG transcription factor in prostate cancer cells activates osteopontin. Molecular cancer research : MCR 9(7), 914-924 (2011).

44. Yu Hongbo, Han Xiaobing, Liang Yizhen, Liu Jiangang, Wang Wei. Expression and clinical significance of OPN and survivin in prostate cancer. Journal of Southern Medical University 30(05), 1141-1143 (2010).

45. Xu M, Jiang H, Wang H, Liu J, Liu B, Guo Z. SB225002 inhibits prostate cancer invasion and attenuates the expression of BSP, OPN and MMP2. Oncology reports 40(2), 726-736 (2018).

46. Wang J, Levenson AS, Satcher RL, Jr. Identification of a unique set of genes altered during cell-cell contact in an in vitro model of prostate cancer bone metastasis. International journal of molecular medicine 17(5), 849-856 (2006).

47. Xia Wenxia, Han Bangcheng. Expression and correlation of survivin and osteopontin in prostate cancer. Medical Laboratory and Clinical 23(4), 83,85 (2012).

48. Wei Can, Zhang Yanbin, Ying Quansheng et al. Expression and clinical significance of breast cancer metastasis suppressor gene and osteopontin in prostate cancer. Chinese Journal of Experimental Surgery 35(12), 2193-2195 (2018).

49. Aksoy A, Artas G, Sevindik OG. Predictive value of stathmin-1 and osteopontin expression for taxan resistance in metastatic castrate-resistant prostate cancer. Pakistan Journal of Medical Sciences 33(3), 560-565 (2017).

50. Bhattacharya IS, Taghavi Azar Sharabiani M, Alonzi R, Hoskin PJ. Hypoxia and angiogenic biomarkers in prostate cancer after external beam radiotherapy (EBRT) alone or combined with high-dose-rate brachytherapy boost (HDR-BTb). Radiotherapy and Oncology 137 38-44 (2019).

51. Hotte SJ, Winquist EW, Stitt L, Wilson SM, Chambers AF. Plasma osteopontin: associations with survival and metastasis to bone in men with hormone-refractory prostate carcinoma. Cancer 95(3), 506-512 (2002).

52. Ramankulov A, Lein M, Kristiansen G, Loening SA, Jung K. Plasma osteopontin in comparison with bone markers as indicator of bone metastasis and survival outcome in patients with prostate cancer. The Prostate 67(3), 330-340 (2007).

53. Vergis R, Corbishley CM, Norman AR et al. Intrinsic markers of tumour hypoxia and angiogenesis in localised prostate cancer and outcome of radical treatment: a retrospective analysis of two randomised radiotherapy trials and one surgical cohort study. The Lancet. Oncology 9 (4), 342-351 (2008).

\section{Tables}


Table 1

Characteristics of the included studies for pathological parameters

\begin{tabular}{|c|c|c|c|c|c|c|c|c|c|c|}
\hline Study & Year & Country & $\begin{array}{l}\text { Prostate } \\
\text { cancer } \\
\text { (age) }\end{array}$ & $\begin{array}{l}\text { Benign } \\
\text { prostatic } \\
\text { hyperplasia } \\
\text { (age) }\end{array}$ & $\begin{array}{l}\text { Normal } \\
\text { prostate } \\
\text { (age) }\end{array}$ & $\begin{array}{l}\text { Method } \\
\text { (thickness) }\end{array}$ & $\begin{array}{l}\text { Definition of } \\
\text { OPN positive }\end{array}$ & $\begin{array}{l}\text { Indicator } \\
\text { reported }\end{array}$ & $\begin{array}{l}\text { Antibody } \\
\text { source }\end{array}$ & $\begin{array}{l}\text { NOS } \\
\text { score }\end{array}$ \\
\hline $\begin{array}{l}\text { Tatina et } \\
\text { al[38] }\end{array}$ & 2011 & Brazil & $\begin{array}{l}29(52- \\
79)\end{array}$ & $18(62-87)$ & $\begin{array}{l}30(18- \\
36)\end{array}$ & $\begin{array}{l}\text { Western } \\
\text { blot }\end{array}$ & have bend & ABCFG & Invitrogen & 9 \\
\hline $\begin{array}{l}\text { Wang et } \\
\text { al[39] }\end{array}$ & 2016 & China & $\begin{array}{l}80(55- \\
85)\end{array}$ & -- & $\begin{array}{l}80(55- \\
85)\end{array}$ & $\begin{array}{l}\text { IHC } \\
\text { (unclear) }\end{array}$ & $\begin{array}{l}>1 \text { points }(\mathrm{IHC} \\
\text { score })\end{array}$ & AEFG & Zymed & 7 \\
\hline $\begin{array}{l}\text { Caruso et } \\
\text { al[26] }\end{array}$ & 2008 & USA & 103 & -- & -- & $\begin{array}{l}\text { IHC } \\
\text { (unclear) }\end{array}$ & intensity > 1 & C & $R \& D$ & 7 \\
\hline $\begin{array}{l}\text { Wu et } \\
\text { al[40] }\end{array}$ & 2005 & China & $\begin{array}{l}46(53- \\
70)\end{array}$ & $12(<40)$ & $6(<40)$ & $\begin{array}{l}\text { IHC } \\
\text { (unclear) }\end{array}$ & $\begin{array}{l}>1 \text { points }(\mathrm{IHC} \\
\text { score })\end{array}$ & ABCEF & Chemicon & 9 \\
\hline $\begin{array}{l}\text { Tilli et } \\
\text { al[41] }\end{array}$ & 2012 & Brazil & $\begin{array}{l}40(41- \\
74)\end{array}$ & $30(58-87)$ & -- & $\begin{array}{l}\text { IHC } \\
\text { (4um) and } \\
\text { RT-PCR }\end{array}$ & $\begin{array}{l}{[O P N a+\text { OPNb }} \\
+ \text { OPNc] } \\
29.34 / 1.75 / 9.0\end{array}$ & $\mathrm{BCD}$ & $\begin{array}{l}\text { Gallus } \\
\text { Immunotech }\end{array}$ & 7 \\
\hline $\begin{array}{l}\text { Zheng et } \\
\text { al[42] }\end{array}$ & 2014 & China & $\begin{array}{l}80(55- \\
86)\end{array}$ & $35(55-82)$ & $\begin{array}{l}35(55- \\
82)\end{array}$ & $\begin{array}{l}\text { IHC } \\
\text { (4um) }\end{array}$ & $\begin{array}{l}>1 \text { points }(\mathrm{IHC} \\
\text { score })\end{array}$ & BCDG & Abbiotec & 7 \\
\hline $\begin{array}{l}\text { Flajollet } \\
\text { et al[43] }\end{array}$ & 2011 & France & $35(63)$ & -- & -- & $\begin{array}{l}\mathrm{IHC} \\
\text { (4um) }\end{array}$ & $\begin{array}{l}>10 \% \text { cells } \\
\text { stained }\end{array}$ & C & Santa Cruz & 7 \\
\hline $\begin{array}{l}\text { Yu et } \\
\text { al[44] }\end{array}$ & 2010 & China & $\begin{array}{l}46(44- \\
70)\end{array}$ & $10(<40)$ & $6(<40)$ & $\begin{array}{l}\mathrm{IHC} \\
\text { (4um) }\end{array}$ & $\begin{array}{l}>1 \text { points }(\mathrm{IHC} \\
\text { score })\end{array}$ & ABCEF & Chemicon & 9 \\
\hline $\begin{array}{l}\text { Xu et } \\
\text { al[45] }\end{array}$ & 2018 & China & $\begin{array}{l}100(54- \\
87)\end{array}$ & -- & -- & $\begin{array}{l}\text { IHC } \\
\text { (unclear) }\end{array}$ & $\begin{array}{l}>1 \text { points }(\mathrm{IHC} \\
\text { score })\end{array}$ & $\mathrm{CDH}$ & $\begin{array}{l}\text { Linghan } \\
\text { Shanghai }\end{array}$ & 7 \\
\hline $\begin{array}{l}\text { Wang et } \\
\text { al[46] }\end{array}$ & 2006 & China & $\begin{array}{l}52(47- \\
83)\end{array}$ & $51(42-81)$ & $\begin{array}{l}50(44- \\
79)\end{array}$ & $\begin{array}{l}\text { IHC } \\
\text { (4um) and } \\
\text { ELISA }\end{array}$ & -- & $\mathrm{H}$ & $R \& D$ & 8 \\
\hline $\begin{array}{l}\text { Tozawa } \\
\text { et al[18] }\end{array}$ & 1999 & Japan & 34 & 12 & -- & $\begin{array}{l}\text { IHC } \\
\text { (unclear) }\end{array}$ & $\begin{array}{l}>10 \% \text { cells } \\
\text { stained }\end{array}$ & BEF & $\mathrm{ABC}$ & 7 \\
\hline $\begin{array}{l}\text { Forootan } \\
\text { et al[32] }\end{array}$ & 2006 & UK & 70(73) & $36(67.5)$ & 10 & $\begin{array}{l}\text { IHC } \\
\text { (unclear) }\end{array}$ & $\begin{array}{l}>10 \% \text { cells } \\
\text { stained }\end{array}$ & $A B C$ & $R \& D$ & 9 \\
\hline $\begin{array}{l}\text { Xia et } \\
\text { al[47] }\end{array}$ & 2012 & China & $\begin{array}{l}108(60- \\
78)\end{array}$ & $100(57-82)$ & -- & $\begin{array}{l}\text { IHC } \\
\text { (4um) }\end{array}$ & $\begin{array}{l}>1 \text { points }(\mathrm{IHC} \\
\text { score })\end{array}$ & BFG & Unknown & 7 \\
\hline $\begin{array}{l}\text { Wei et } \\
\text { al[48] }\end{array}$ & 2018 & China & $\begin{array}{l}46(59- \\
86)\end{array}$ & 29 & -- & $\begin{array}{l}\mathrm{IHC} \\
\text { (unclear) }\end{array}$ & $\begin{array}{l}>1 \text { points }(\mathrm{IHC} \\
\text { score })\end{array}$ & $\mathrm{BCDH}$ & Biosin & 7 \\
\hline \multicolumn{11}{|c|}{$\begin{array}{l}\text { Notes: IHC = Immunohistochemistry. ELISA: Enzyme-linked immunosorbent assay. IHC sore: The unstained, weakly stained, moderately stained } \\
\text { and strongly stained cells were given } 0,1,2,3 \text { scores, separately. Indicator reported: A: OPN with prostate cancer tissues and normal prostate } \\
\text { tissues; B: OPN with prostate cancer tissues and benign prostate hyperplasia tissues; C: OPN with Gleason score of prostate cancer tissues; D: } \\
\text { OPN with clinical TNM stage of prostate cancer tissues; E: OPN with clinical Whitmore stage of prostate cancer tissues; F:OPN with the } \\
\text { differentiation of prostate cancer tissues; G: OPN with lymph node metastatic of prostate cancer tissues H: OPN with organ or bone metastatic } \\
\text { prostate cancer tissues }\end{array}$} \\
\hline
\end{tabular}


Table 2

Characteristics of the included studies for survival analysis

\begin{tabular}{|c|c|c|c|c|c|c|c|c|c|c|c|}
\hline Study & Year & Country & $\begin{array}{l}\text { Cancer } \\
\text { types }\end{array}$ & patients & $\begin{array}{l}\text { Median } \\
\text { age } \\
\text { [Range] } \\
\text { (years) }\end{array}$ & $\begin{array}{l}\text { Follow- } \\
\text { up time }\end{array}$ & $\begin{array}{l}\text { Counting } \\
\text { Method }\end{array}$ & $\begin{array}{l}\text { Cut-off value } \\
\text { (positive/high) }\end{array}$ & $\begin{array}{l}\text { Survival } \\
\text { outcomes }\end{array}$ & $\begin{array}{l}\text { Source } \\
\text { of } \\
\text { data }\end{array}$ & $\begin{array}{l}\text { NOS } \\
\text { score }\end{array}$ \\
\hline $\begin{array}{l}\text { Aksoy A et } \\
\text { al[49] }\end{array}$ & 2017 & Turkey & mCRPC & 30 & -- & NR & $\mathrm{IHC}$ & $A>50$ & $\begin{array}{l}\text { OS(U), } \\
\text { OS(M) }\end{array}$ & $\begin{array}{l}\text { curve } \\
+ \\
\text { direct }\end{array}$ & 6 \\
\hline $\begin{array}{l}\text { Bhattacharya } \\
\text { IS et al[50] }\end{array}$ & 2019 & UK & LPC & 218 & -- & $\begin{array}{l}85 \\
\text { months } \\
\text { (median) }\end{array}$ & $\mathrm{IHC}$ & Median scores & $\begin{array}{l}\text { BRFS(U), } \\
\text { BRFS(M) } \\
\text { DMFS(U) }\end{array}$ & direct & 7 \\
\hline $\begin{array}{l}\text { Dayyani F et } \\
\text { al[14] }\end{array}$ & 2016 & USA & mADPC & 66 & $\begin{array}{l}72 \\
{[57,93]}\end{array}$ & $\begin{array}{l}1.4- \\
2.6 \text { years }\end{array}$ & ELISA & $\ln (\mathrm{OPN})>11.9$ & $\begin{array}{l}\text { PFS(U), } \\
\text { PFS(M) }\end{array}$ & direct & 7 \\
\hline $\begin{array}{l}\text { Forootan SS } \\
\text { et al[32] }\end{array}$ & 2006 & UK & $\mathrm{PA}$ & 70 & 73 & $\begin{array}{l}0-80 \\
\text { months }\end{array}$ & $\mathrm{IHC}$ & $A>30$ & $\operatorname{os}(U)$ & curve & 6 \\
\hline $\begin{array}{l}\text { Hotte SJ et } \\
\text { al[51] }\end{array}$ & 2002 & Canada & HRPC & 100 & $\begin{array}{l}73 \\
{[50-} \\
86]\end{array}$ & $\begin{array}{l}0-26 \\
\text { months }\end{array}$ & ELISA & $>115 \mathrm{ng} / \mathrm{ml}$ & $\begin{array}{l}\text { OS(U), } \\
\text { OS(M) }\end{array}$ & $\begin{array}{l}\text { curve } \\
+ \\
\text { direct }\end{array}$ & 8 \\
\hline $\begin{array}{l}\text { Ramankulov } \\
\text { A et al[52] }\end{array}$ & 2007 & Germany & PC & 90 & -- & $\begin{array}{l}2.7-88.4 \\
\text { months }\end{array}$ & ELISA & > 1099 ug/L & $\begin{array}{l}\text { DSS(U), } \\
\text { DSS(M) }\end{array}$ & direct & 8 \\
\hline $\begin{array}{l}\text { Vergis R et } \\
\text { al[53] }\end{array}$ & 2008 & UK & LPC & $\begin{array}{l}\text { I: } 201 \\
\text { II: } 285\end{array}$ & $\begin{array}{l}\text { I: } 67 \\
{[50,80]} \\
\text { II: } 61 \\
{[45-} \\
78]\end{array}$ & -- & $\mathrm{IHC}$ & $A>0$ & $\begin{array}{l}\text { BRFS(U), } \\
\text { BRFS(M) }\end{array}$ & direct & 7 \\
\hline $\begin{array}{l}\text { mCRPC: meta } \\
\text { PA: prostate a } \\
\text { radical prosta } \\
\text { relapse-free su } \\
\text { analysis, M: } m\end{array}$ & $\begin{array}{l}\text { ic cas } \\
\text { ocarc } \\
\text { omy } \\
\text { val, DI } \\
\text { variat }\end{array}$ & $\begin{array}{l}\text { te-resista } \\
\text { ma, HRP } \\
\text { ort. IHC: i } \\
\text { S: distant } \\
\text { nalysis. I }\end{array}$ & $\begin{array}{l}\text { prostate } \\
\text { hormone } \\
\text { munohis } \\
\text { letastasi } \\
\text { S: Newc }\end{array}$ & $\begin{array}{l}\text { ncer, LP } \\
\text { fractory } \\
\text { hemistr } \\
\text { ee survi } \\
\text { le-Ottaw }\end{array}$ & $\begin{array}{l}\text { ocalized } \\
\text { state ca } \\
\text { ISA: en } \\
\text { PFS: pr } \\
\text { cale. A: }\end{array}$ & $\begin{array}{l}\text { state can } \\
\text { loma, PC: } \\
\text { le-linked ir } \\
\text { ession-free } \\
\text { centage of }\end{array}$ & $\begin{array}{l}\text { r, mADPC } \\
\text { ostate ca } \\
\text { munosorb } \\
\text { urvival, D } \\
\text { ositive ce }\end{array}$ & $\begin{array}{l}\text { etastatic andro } \\
\text { r. Cohort I: radi } \\
\text { assay. OS: ov } \\
\text { disease-speci }\end{array}$ & $\begin{array}{l}\text { n-depende } \\
\text { lerapy coh } \\
\text { II survival, } \\
\text { survival. U. }\end{array}$ & $\begin{array}{l}\text { orostate } \\
\text { Cohort I } \\
\text { FS: biocl } \\
\text { hivariate }\end{array}$ & $\begin{array}{l}\text { incer, } \\
\text { mical }\end{array}$ \\
\hline
\end{tabular}

\section{Figures}




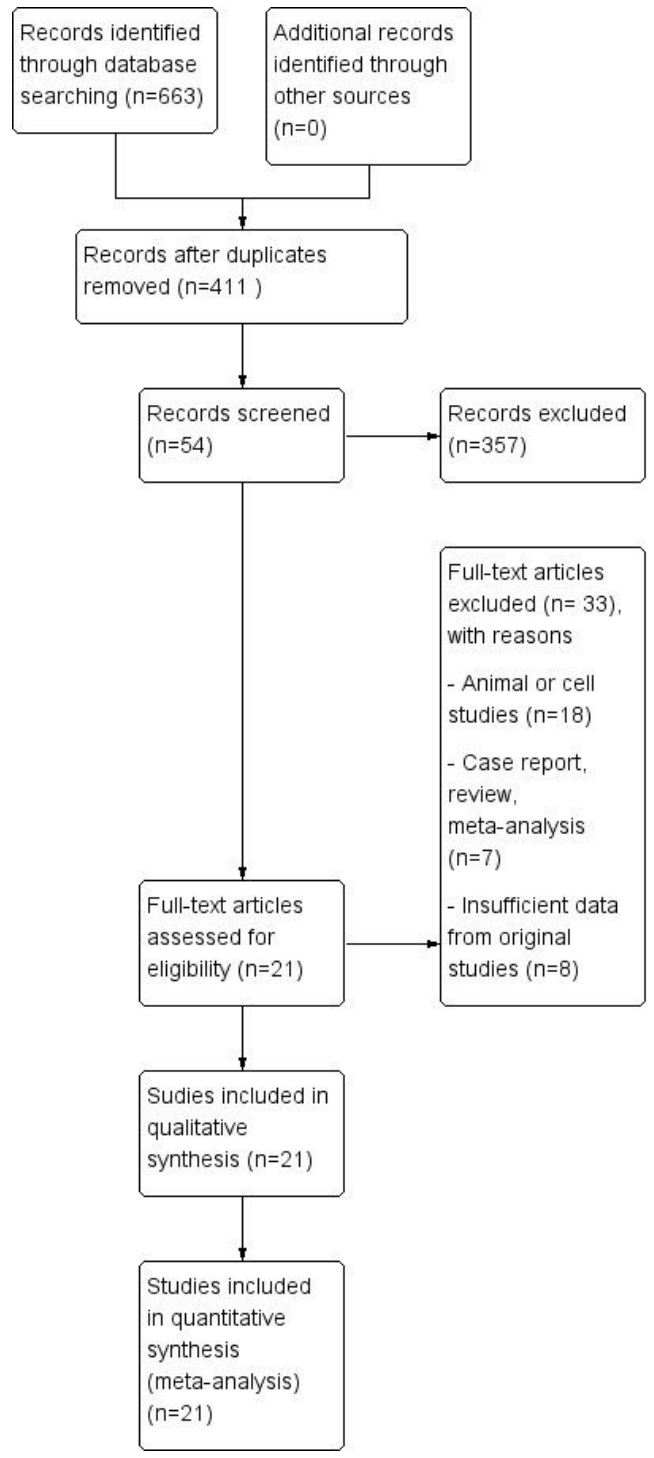

Figure 1

Flowchart of the included studies for meta-analysis. A total of 663 studies were identified, and 252 studies were excluded because of duplication. 357 studies were excluded after reading the abstract because of not related. 54 possible studies were ful text reviewed and 33 studies were excluded because pf animal or cell studies $(n=18)$, case report, meta-analysis and review $(n=7)$, insufficient data ( $n=6)$. Finally, 21 studies were included for quantitative analysis 


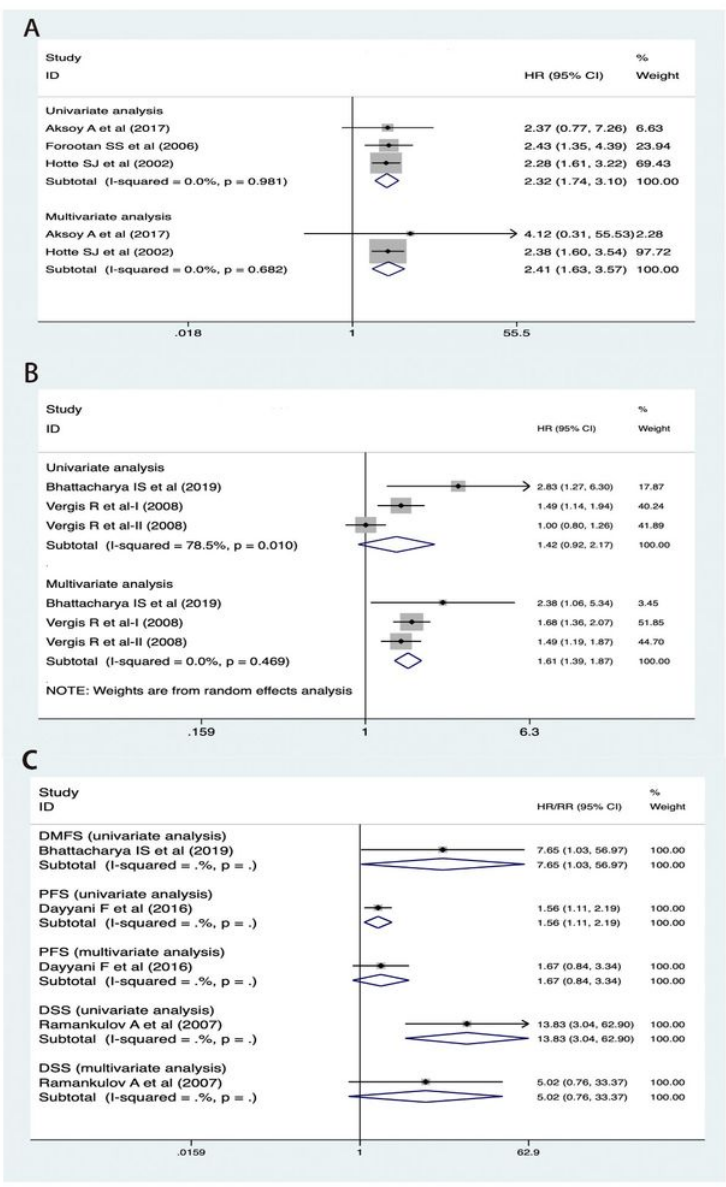

Figure 2

The forest plot of the expression of OPN and survival analysis (A) The relationship of OPN expression and overall survival (both univariate and multivariate analysis) and the result shoed that OPN positive group had a lower overall survival than the negative group (B) The relationship of OPN expression and biochemical relapse-free survival (both univariate and multivariate analysis) and the result shoed that OPN positive group had a lower biochemical relapse-free survival than the negative group (C) The relationship of OPN expression and other kind of survival analysis. (DMFS: distant metastasis-free survival, PFS: progression-free survival, DSS: disease-specific survival.) 


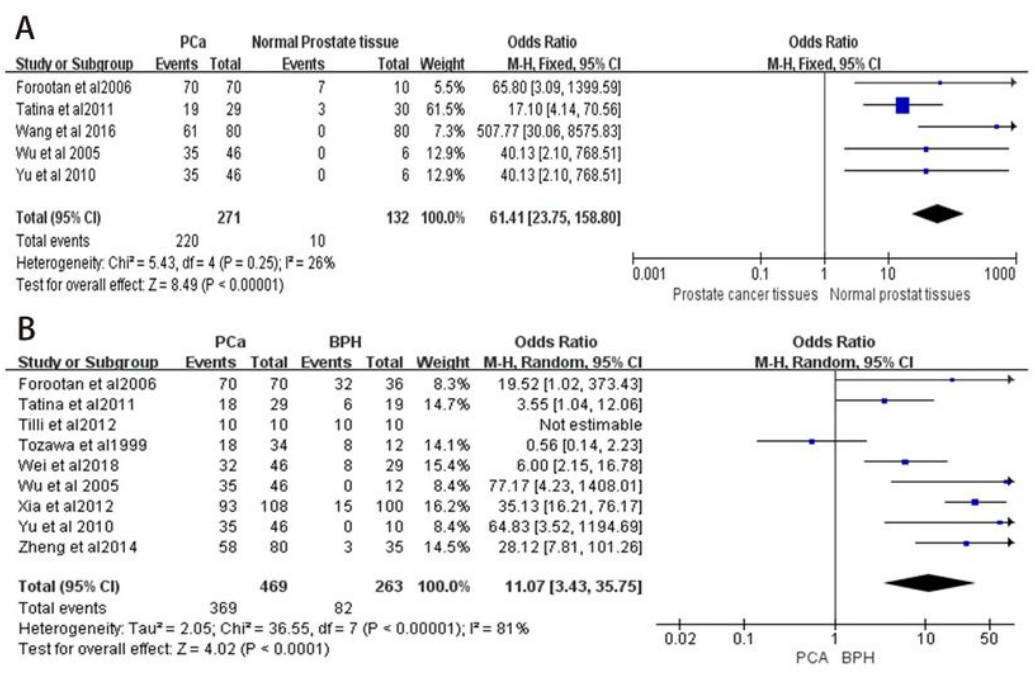

\section{Figure 3}

The forest plot of the expression of OPN and different prostate tissues (A) OPN positive expression in prostate cancer tissues and normal prostate tissues. The result showed that OPN in prostate cancer tissues was significantly higher than that in normal prostate cancer tissues. (OR=46.55, $95 \% \mathrm{Cl}[12.85,168.59], \mathrm{p}<0.00001)(\mathrm{B})$ OPN positive expression in prostate cancer tissues and benign prostatic hyperplasia tissues. The result showed that OPN in prostate cancer tissues was significantly higher than that in benign prostatic hyperplasia tissues. (OR=11.07, $95 \% \mathrm{Cl}[3.43$, 35.75], $p<0.0001$ ) 


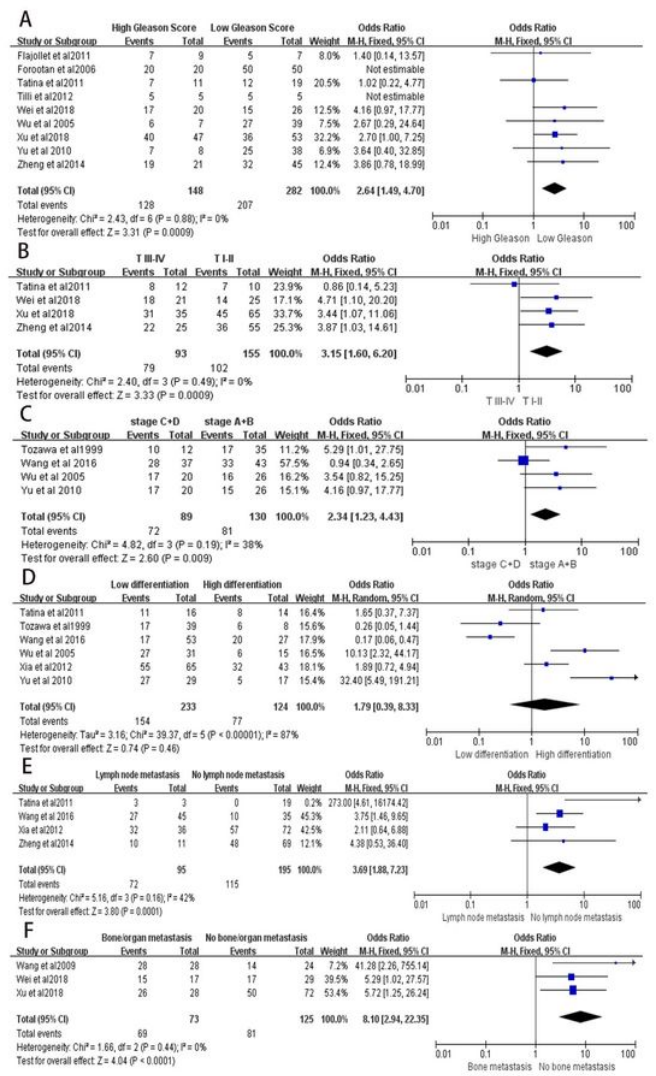

\section{Figure 4}

The forest plot of the expression of OPN and clinical pathological features of prostate cancers (A) The relationship between OPN positive expression and Gleason score. The result showed that the positive rate of OPN in high Gleason score patients was significantly higher than the ones with low Gleason score $(\mathrm{OR}=2.64,95 \% \mathrm{Cl}[1.49,4.70], \mathrm{p}=0.0009)$. (B) The relationship between OPN positive expression and clinical stage. The result showed that the expression level of OPN in T III-IV stage is higher than that in T I-II stage of prostate cancer patients. (OR=3.15, 95\% $\mathrm{Cl}[1.60,6.20$, $\mathrm{p}=0.0009)$. (C) The relationship between OPN positive expression and Whitmore-Jewett stage. The expression level of OPN in Whitmore-Jewett stage $C+D$ patients is higher than in stage $A+B$ patients. $(O R=2.53,95 \% \mathrm{Cl}[1.06,6.03], p=0.04)$. (D) The relationship between OPN positive expression and the differentiation of prostate cancer. The expression of OPN have no difference between high and low differentiation of prostate cancer tissues. $(\mathrm{OR}=1.79,95 \% \mathrm{Cl}[0.39,8.33], \mathrm{p}=0.46)$. (E) The relationship between OPN positive expression and the lymph node metastasis. The expression of OPN is positively correlated with lymph node metastasis of prostate cancer. $(\mathrm{OR}=3.69,95 \% \mathrm{Cl}[1.88,7.23], \mathrm{p}=0.0001)$. $(\mathrm{F}) \mathrm{The}$ relationship between OPN positive expression and distant metastasis of prostate cancer. The expression of OPN is positively correlated with distant metastasis of prostate cancer. $(\mathrm{OR}=8.10,95 \% \mathrm{Cl}[2.94,22.35], \mathrm{p}=0.01)$ 

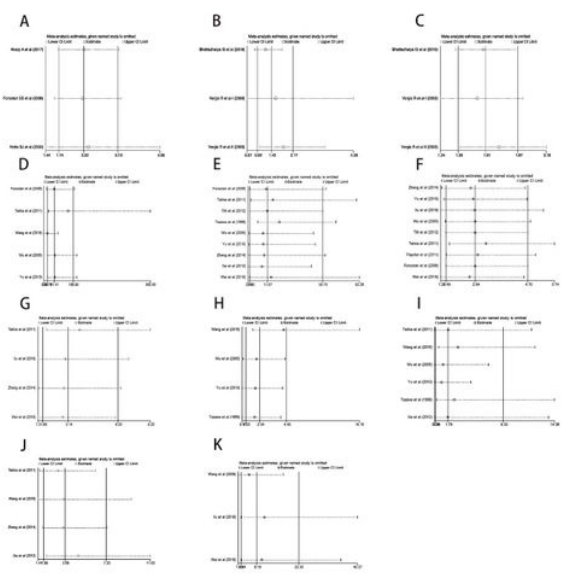

\section{Figure 5}

The sensitivity analysis of each analysis. (A) The expression of OPN and overall survival (univariate analysis) (B) The expression of OPN and biochemical relapse-free survival (univariate analysis) (C) The expression of OPN and biochemical relapse-free survival (multivariate analysis) (D) The positive expression of OPN between prostate cancer tissues and normal prostate tissues (E) The positive expression of OPN between prostate cancer tissues and benign prostatic hyperplasia tissues (F) The positive expression of OPN with Gleason score (G) The positive expression of OPN with clinical stage $(\mathrm{H})$ The positive expression of OPN with Whitmore-Jewett stage (I) The positive expression of OPN with differentiation of prostate cancer $(\mathrm{J})$ The positive expression of OPN with lymph node metastasis of prostate cancer (K) The positive expression of OPN with distant metastasis of prostate cancer 
A

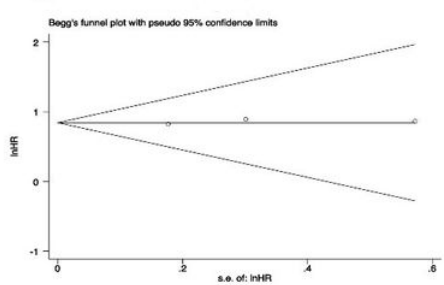

D

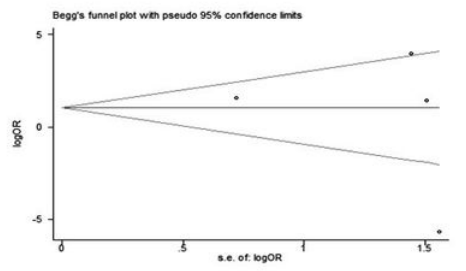

G

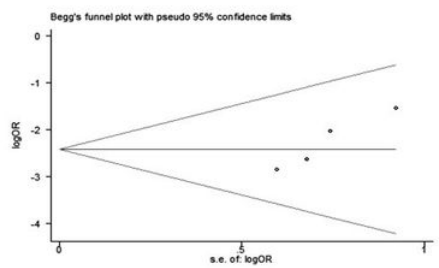

J

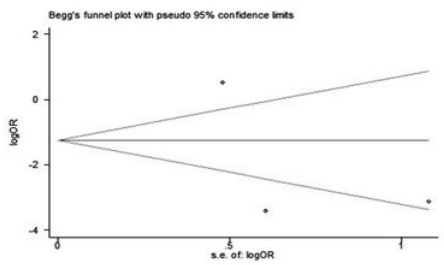

\section{B}

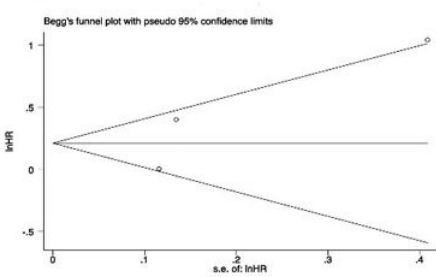

E

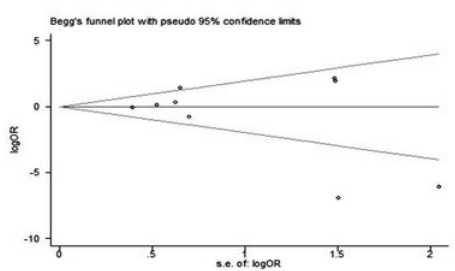

H

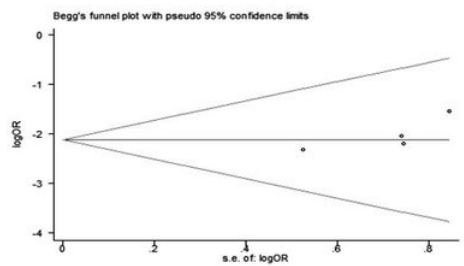

K

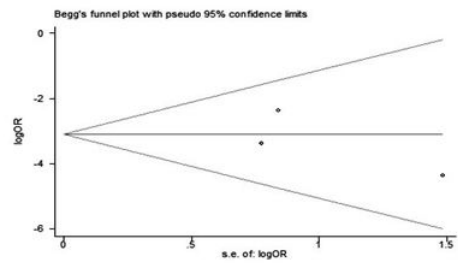

C

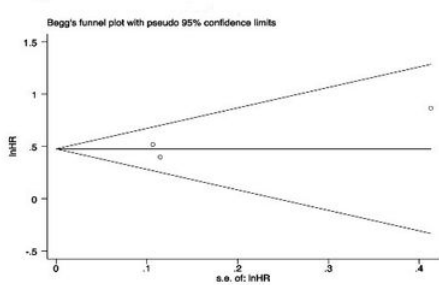

F

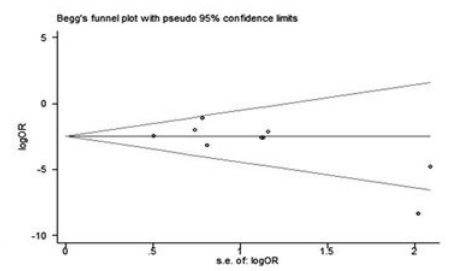

I

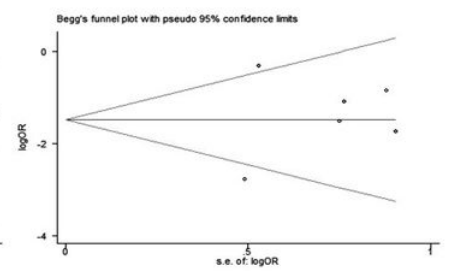

\section{Figure 6}

Publication bias (A) The expression of OPN and overall survival (univariate analysis) (B) The expression of OPN and biochemical relapse-free survival (univariate analysis) (C) The expression of OPN and biochemical relapse-free survival (multivariate analysis) (D) The positive expression of OPN between prostate cancer tissues and normal prostate tissues (E) The positive expression of OPN between prostate cancer tissues and benign prostatic hyperplasia tissues (F) The positive expression of OPN with Gleason score (G) The positive expression of OPN with clinical stage (H) The positive expression of OPN with Whitmore-Jewett stage (I) The positive expression of OPN with differentiation of prostate cancer ( $\mathrm{J}$ ) The positive expression of OPN with lymph node metastasis of prostate cancer (K) The positive expression of OPN with distant metastasis of prostate cancer

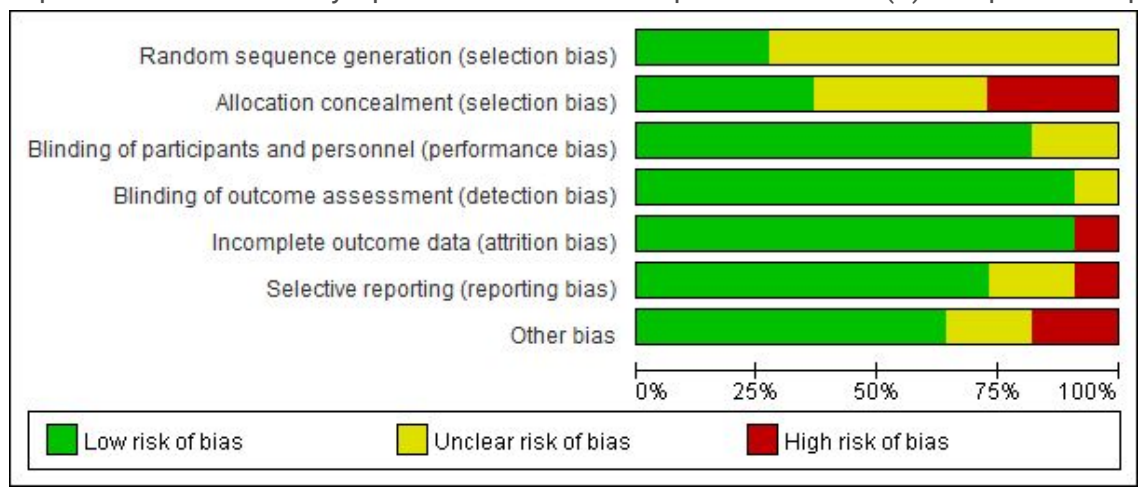

\section{Figure 7}

Risk of publication bias summary diagram Diagram showed the source and risk of potential bias 